\title{
A new aeduellid actinopterygian from the Lower Permian of the Krkonoše Piedmont Basin (Bohemian Massif) and its relationship to other Aeduellidae
}

\author{
STANISLAV ŠTAMBERG
}

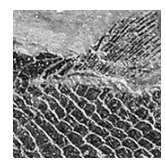

\begin{abstract}
A new aeduellid actinopterygian, Neslovicella elongata sp. nov., is described from the Lower Permian of the Krkonoše Piedmont Basin (Bohemian Massif). The new taxon is based upon a collection of specimens that facilitated the revision of several characters of the Aeduellidae. N. elongata is described in detail and compared to other aeduellids. A second occurrence of this species in the Weissig Basin of Germany is also discussed. $\bullet$ Key words: Actinopterygii, anatomy, systematics, Lower Permian, Bohemian Massif.
\end{abstract}

\begin{abstract}
S̆TAMBERG, S. 2010. A new aeduellid actinopterygian from the Lower Permian of the Krkonoše Piedmont Basin (Bohemian Massif) and its relationship to other Aeduellidae. Bulletin of Geosciences 85(2), 183-198 (13 figures, 1 table). Czech Geological Survey, Prague. ISSN 1214-1119. Manuscript received February 26, 2010; accepted in revised form May 13, 2010; published online June 9, 2010; issued June 30, 2010.
\end{abstract}

Stanislav Štamberg, Regional Museum of Eastern Bohemia, Eliščino nábřeži 465, 50001 Hradec Králové, Czech Republic; s.stamberg@muzeumhk.cz.

Actinopterygians of the family Aeduellidae are abundant in the Permocarboniferous basins of the French Massif Central. The type genus Aeduella (see Heyler 1969 for a detailed description) is very common in the Muse Formation of the Bassin d'Autun, in the Bourbon l'Archambault Basin at Buxières-les-Mines, and in other localities. Other aeduellid genera are also known from the French Massif Central (Heyler 2000, Poplin 2001). However, representatives of this family have been subsequently described from Germany (Heyler 1991, Uhl 1997), northern Switzerland (Bürgin 1990), Spain (Forey \& Young 1985) and New Mexico (Gottfried 1987). Until recently, the only aeduellid taxa reported from Czech Republic basins were Spinarichthys dispersus (Fritsch, 1895) from the Stephanian C of Central Bohemia (Štamberg 1986, 2006) and Aeduella sp., known from several isolated bones in the Lower Permian of the Krkonoše Piedmont Basin (Štamberg 2002). Poplin \& Dutheil (2005) published a summary of all aeduellid occurrences known at that time, and included a list of their diagnostic features. Recent extensive fieldwork has revealed that aeduellids constitute a substantial faunistic component in the Lower Permian of the Bohemian Massif. Two recently described species, Bourbonnella hirsuta Štamberg, 2007a and Neslovicella rzehaki Stamberg, 2007a, occur in the Lower Permian of the Boskovice Graben, where $N$. rzehaki is particularly well represented.

The following fourteen species of the family Aeduellidae have been described to date: Aeduella blainvillei (Agassiz,
1833); Neslovicella rzehaki Štamberg, 2007; Bourbonnella guilloti Heyler, 1967; Bourbonnella fourrieri Poplin, 2001; Bourbonnella sottyi (Heyler, 1977); Bourbonnella hirsuta Štamberg, 2007; Decazella vetteri (Heyler, 1964); Platysella lallyi Heyler \& Poplin, 1983; Platysella descusi Heyler \& Poplin, 1983; Platysella poplinae Heyler, 2002; Puertollanichthys ritchiei Forey \& Young, 1985; Schafeevus sulcatus Yankevich \& Minich, 1998; Spinarichthys dispersus (Fritsch, 1895); Westollia crassa (Pohlig, 1892).

The family Aeduellidae seems to be a homogeneous group, and it possesses several features which distinguish them from the other lower actinopterygians. The interrelationships within the family Aeduellidae and between aeduellids and other lower actinopterygians have been studied by several authors. Heyler (1969) pointed out the affinity of aeduellids with Mesopoma, Canobius and the Haplolepididae. Heyler (1969) suggested a possible phylogenetical progression from Mesopoma and Canobius to the Aeduellidae, and that the Aeduellidae could be placed somewhere along the line between chondrosteans and holosteans.

Gardiner \& Schaeffer (1989) placed aeduellids within the "Aeduella group" encompassing Aeduella Westoll, 1937; Decazella Heyler, 1969; Bourbonnella Heyler, 1969 together with brookvaliiform Igornella Heyler, 1969. They considered this group to be monophyletic and characterized by a blunt, rounded snout and a toothless premaxilloantorbital that is mostly or entirely excluded from upper jaw margin. 


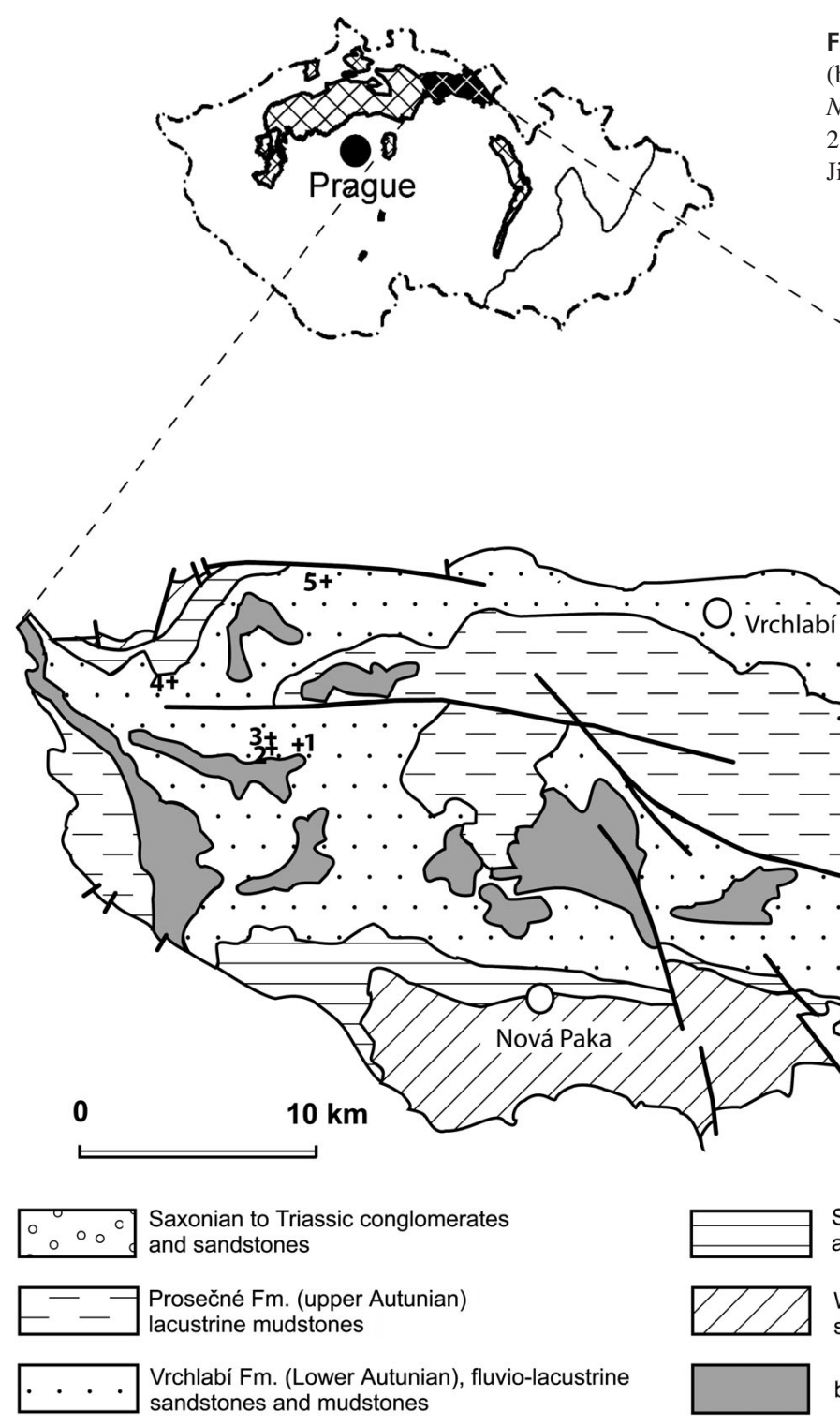

A separate lineage leading from the Aeduellidae to the Semionotidae, Pycnodontiformes and Lepisosteidae was introduced by Arratia (2004, fig. 1) on her phylogenetic scheme which was modified from Gardiner (1960).

Poplin \& Dutheil (2005) presented a phylogenetic analysis of lower actinopterygians involving ten species of Aeduellidae, five species with which aeduellids were compared in the past, and six other well known palaeoniscimorphs, and a porolepiform outgroup. The phylogenetic analysis suggests that the Aeduellidae form a natural group, but they show no particular affinities with the groups with which they have been compared in the past. Poplin \& Dutheil (2005) identified six important features of the Aeduellidae: A mosaic of small suborbitals without ganoin, presence of tubular teeth on the upper and lower jaws, preopercular not reaching the skull roof, junction of the supraorbital and infraorbital
Figure 1. A simplified geological map of the Krkonoše Piedmont Basin (based on Blecha et al. 1999, Zajíc 2007) showing the occurences of Neslovicella elongata sp. nov. 1 - Koštálov "Behind the Tavern"; 2 - Kundratice "Doly"; 3 - Kundratice "Gorge"; 4-Semily "Left Bank of Jizera River"; 5 - Rybnice "Hrádecký Creek".
Semily Fm. (Stephanian C); alluvial fan conglomerates, fluvial sandstones and lacustrine mudstones (with coal)

Westphalian D to Stephanian B; basal conglomerates, fluvio-lacustrine sandstones and mudstones (with coal)

basaltic andesites to trachyandesites

canals situated on the dermopterotic, pit line marking the entrance of the supraorbital canal onto the dermopterotic.

Abundant actinopterygian material has been recently excavated from several localities in the Rudník Horizon (Vrchlabí Formation, Asselian) of the Krkonoše Piedmont Basin (Bohemian Massif). The material includes a new aeduellid species of the genus Neslovicella, reported here. The present paper aims to provide a detailed description of the new taxon, to compare it with specimens from the Weissig Basin near Dresden, Germany, and to determine its affinities with other Aeduellidae.

Institutional abbreviations. - M - National Museum, Prague; MHK - Museum of Eastern Bohemia at Hradec Králové; NHMW - Naturhistorisches Museum, Wien; SaP - Staatliches Naturhistorisches Museum, Dresden. 


\section{Material and methods}

Material. - The new taxon is based upon thirty-four specimens from the Krkonoše Piedmont Basin, including both juveniles and adults. The fossil-bearing sediments are found in several localities of the Rudník Horizon (Vrchlabí Formation, Asselian). Most of the specimens were collected by the author during the last 15 years from the following localities: Koštálov ("Behind the Tavern"), Kundratice ("Doly"), Kundratice ("Gorge"), Semily ("Left Bank of Jizera River") and Rybnice ("Hrádecký Creek"). Nine well-preserved specimens from the same localities belong to collections of Mr M. Lapacík (Turnov), and have been recently donated to the Museum of Eastern Bohemia, Hradec Králové. Five additional specimens from the village of Koštálov were collected at the end of the $19^{\text {th }}$ century by Mr J. Benda, and are now deposited in the National Museum, Prague. One well-preserved specimen (Štamberg 2007b) from the same collector is deposited in the Natural History Museum in Vienna (Naturhistoriches Museum, Wien). Three other specimens from Weissig (Weissig Basin near Dresden; Asselian) are in the collections of the Staatliches Naturhistorisches Museum, Dresden.

Methods. - The descriptive terminology conforms to that adopted by Grande \& Bemis (1998) with inclusion of some terms after Poplin \& Lund (1997) and Štamberg (2007a). Observation, drawing and measurement methods are the same as those described by Štamberg (2007a).

\section{Systematic palaeontology}

Subclass Actinopterygii Cope, 1887

Family Aeduellidae Romer, 1945

\section{Genus Neslovicella S̆tamberg, 2007a}

Type species. - Neslovicella rzehaki Štamberg, 2007a.

Emended diagnosis. - Fusiform body with a maximum total length of $103 \mathrm{~mm}$. Pectoral fin with scale-covered lobe. Lepidotrichia of the pectoral fin articulated along their entire length. Leading edge of the pectoral fin turned dorsally. Dorsal fin origin situated above the space between the pelvic fin and anal fin base. Dorsal and anal fins approximately equal in size, or anal fin slightly smaller. Caudal fin deeply incised and inequilobate. Scale-covered axis of dorsal lobe of caudal fin forming low angle with anteroposterior body axis. Caudal inversion abrupt. Frontals wide, with a length/width ratio of 1.06-1.25. Frontal/parietal length ratio 1.06-1.7. Interparietal-interfrontal suture almost straight. Dermosphenotic elongate. Supraorbital sensory canal extending from the nasal posteriorly across the frontal, turning laterally on frontal and continuing onto the dermopterotic. Orbit large. Numerous postorbital bones. Preopercular very small. Maxilla with triangular maxillary plate posteriorly. In adult specimens the maxilla length/height ratio is 2.2. Lower jaw weak, slightly turned ventrally at the oral extremity. Jaw dentition consisting of numerous minuscule tubular teeth. Opercular very high, curved orally in its dorsal region. Opercular axis inclined at about 60 degrees to the horizontal. Opercular as tall as the subopercular or shorter. Opercular-subopercular suture oblique, two branchiostegal rays present. Posterior margin of scales conspicuously pectinate.

Included species. - Neslovicella rzehaki Štamberg, 2007a; Neslovicella elongata sp. nov.

\section{Neslovicella elongata sp. nov.} Figures 2-13, Table 1

Derivation of name. - Latin, longus, with reference to the elongate body of the fish.

Holotype. - MHK 80447, showing well preserved body (including fins) and outline of the head with orbit, upper jaw and opercular (Fig. 13C).

Referred material. - M 2705, 2710, 2718, 2722, 4882; MHK 19810, 30744, 30881, 30884, 30890, 30897, 64730, 64732, 64733, 64836, 64837, 64843, 64844, 64846, 80149, 80448-80459, 81368, 81369; NHMW 1901/VII/6; SaP 15, 16,752 .

Type horizon and locality. - Koštálov ("Behind the Tavern”); Rudník Horizon, Vrchlabí Formation, Asselian, Krkonoše Piedmont Basin.

Occurence. - Koštálov ("Behind the Tavern"), Kundratice ("Doly"), Kundratice ("Gorge"), Semily ("Left Bank of Jizera River”), Rybnice (“Hrádecký Creek”) (Rudník Horizon, Vrchlabí Formation, Asselian, Krkonoše Piedmont Basin); Weissig near Dresden (Weissig Formation, Weissig Basin, Lower Permian).

Diagnosis. - Small aeduellid with elongate body, more slender than in N. rzehaki, not exceeding $75 \mathrm{~mm}$ in total length. The total body length being 5 times the head length, and 5.1 times the maximum body height. Length of anal fin slightly shorter than the length of the dorsal fin. Base of the anal and dorsal fins without any field of small scales. Caudal peduncle long. Dorsal scaled lobe of caudal fin orientated at 20-25 degrees relative to the body axis. Frontal/parietal length ratio about 1.1. Orbit large. Small suborbital bones posterior to orbit. Length of maxilla 2.2 times 


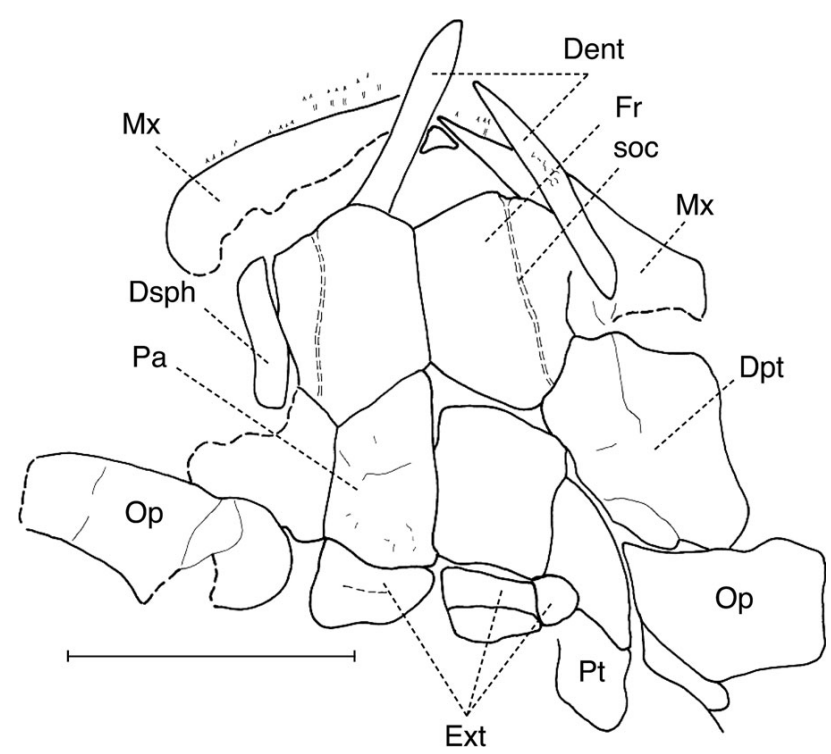

Figure 2. Neslovicella elongata sp. nov., skull roof in dorsal view and fragments of the jaws and the bones of the opercular apparatus in MHK 80492. Scale bar represents $5 \mathrm{~mm}$. Abbreviations: Dent - lower jaw; Dpt - dermopterotic; Dsph - dermosphenotic; Ext - extrascapular; Fr - frontal; Mx - maxilla; Op - opercular; $\mathrm{Pa}$ - parietal; soc - supraorbital sensory canal; $\mathrm{Pt}$ - posttemporal.
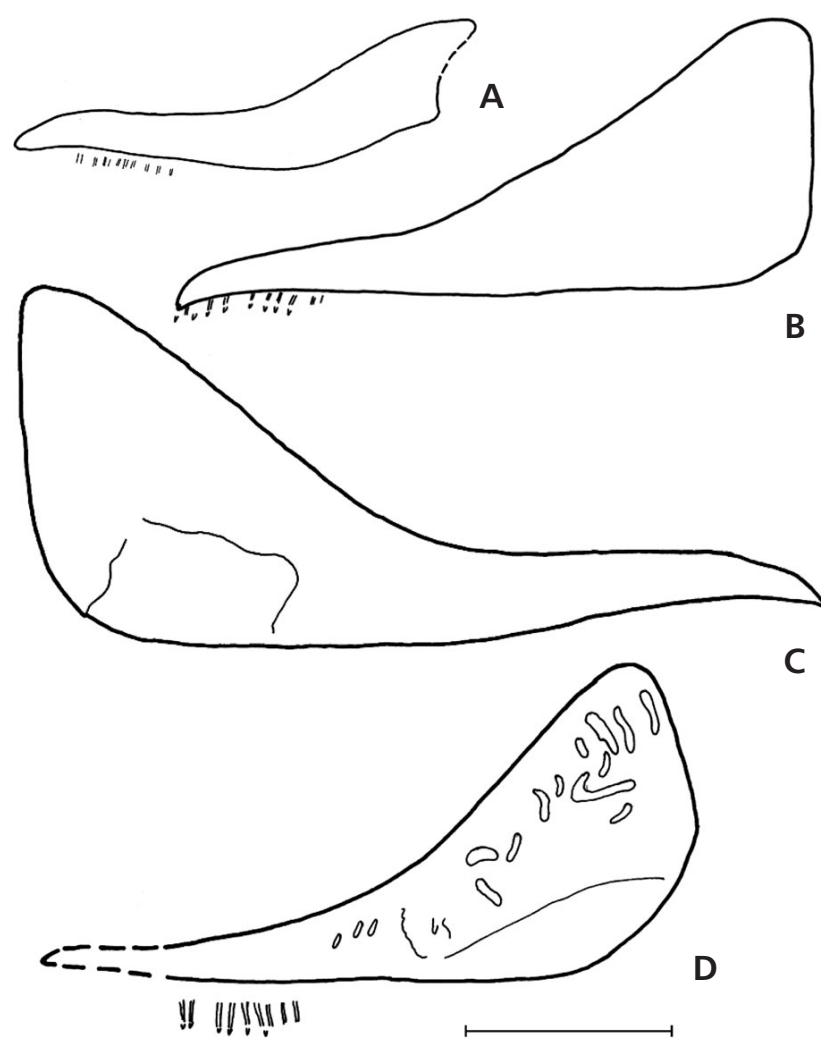

Figure 3. Neslovicella elongata sp. nov., maxillaries in lateral view. -A - MHK 30881; B - M 4882; C - SaP 752; D - SaP 16. Scale bar represents $2 \mathrm{~mm}$. its height. Very small axe-shaped preopercular with vertically orientated anterior margin in its dorsal region. Opercular very tall, its height being equal to that of the subopercular. Opercular-subopercular suture oblique. Two branchiostegal rays. One pair of lateral gular. Posterior margin of trunk scales conspicuously pectinate. Scale count as follows:

$$
\frac{26}{9 \quad 24 \quad 36} 40 \text {. }
$$

\section{Comparative description}

Neslovicella elongata sp. nov. is a small aeduellid with a total body length ranging from $28 \mathrm{~mm}$ (MHK 30897) to $75 \mathrm{~mm}$ (MHK 64846, M 2722). The elongate, fusiform body does not show any dorsal elevation. The total body length is estimated to be 5.1 times that of the deepest part of the body, but the body length/depth ratio varies from 4.6 to 6.2 , depending upon specimen preservation and the degree of deformation (Table 1). The dorsal fin originates relatively far back along the dorsal midline, beyond the level of the pelvic fins. The caudal peduncle is long. The caudal fin is deeply cleft and the axis of its dorsal lobe forms a low angle with the body axis.

\section{Head}

The skull roof is comprised of paired frontal, parietal, dermopterotic and dermosphenotic plus two paired extrascapulars lateral. Information on the skull roof bones is gleaned mostly from MHK 80447, MHK 30890, MHK 30897 MHK 30744, and others. The rostral region is not well preserved, but a juvenile specimen, MHK 30744, shows fragments of the nasal with a tract of the supraorbital canal proceeding from the frontal onto the nasal (Fig. 5). Poorly preserved rostral regions can barely be recognised in MHK 80457 and MHK 80458 (Fig. 4).

The oblong-shaped frontal is short and wide (MHK 80452, Fig. 2), with a length/width ratio of 1.36. No dermal ornamentation is observed on the dorsal surface of the bone. The interfrontal suture is straight. The lateral margin of the frontal does not have any processes, and abuts the dermosphenotic. The anterior margin is mostly convex anteriorly, but its medial part is concave and presumably accommodated the postrostral in life. The posterior margin of the frontal is deeply wedged between the parietal medially and the dermopterotic laterally. The frontal supraorbital canal is conspicuous. It follows a slighty curved course near the lateral margin of the bone, and probably continues onto the dermopterotic after straddling the lateral part of the posterior margin of the frontal as in other aeduellids (Heyler 1969, Stamberg 2007a). 
Table 1. Scale counts and anatomical measurements of selected specimens of Neslovicella elongata sp. nov. All measurements are expressed in mm and indicated as follows: 1 - the scale count according to the formula proposed by Westoll (1944). The numbers in the fraction indicate the number of scale rows dividing the supracleithrum from the insertion of the dorsal (number in numerator), pelvic (first number in denominator), anal (second number in denominator) and caudal fins (third number in denominator). The number behind the fraction indicates the number of scale rows dividing the supracleithrum from the caudal inversion. 2 - total body length, measured along the horizontal body axis from the rostral tip to the posterior extremity of the caudal fin dorsal lobe. 3 - trunk length, measured along the horizontal body axis from the posterior margin of the supracleithrum to the apex of the angle formed by dorsal and ventral lobes of the caudal fin. 4 - distance between the posterior margin of the supracleithrum and anterior margin of the dorsal fin base; $4_{1}$ - length of dorsal fin base; $4_{2}$ - number of dorsal fin lepidotrichia; $4_{3}$-length of longest lepidotrichium in the dorsal fin. 5 - distance between posterior margin of the supracleithrum and anterior margin of the anal fin base; $5_{1}-$ length of anal fin base; $5_{2}-$ number of anal fin lepidotrichia; $5_{3}-$ length of longest lepidotrichium in the anal fin. 6 - distance between the posterior margin of the supracleithrum and anterior margin of the pelvic fin base; $6_{1}-$ length of pelvic fin base; $6_{2}$ - number of pelvic fin lepidotrichia; $6_{3}-$ length of longest lepidotrichium in the pelvic fin. $7_{1}-$ length of caudal fin dorsal lobe; $7_{2}$ - length of caudal fin ventral lobe. 8 - maximum body height. 9 - height of caudal peduncle. 10 - head length, measured from the rostral tip to posterior margin of the supracleithrum.





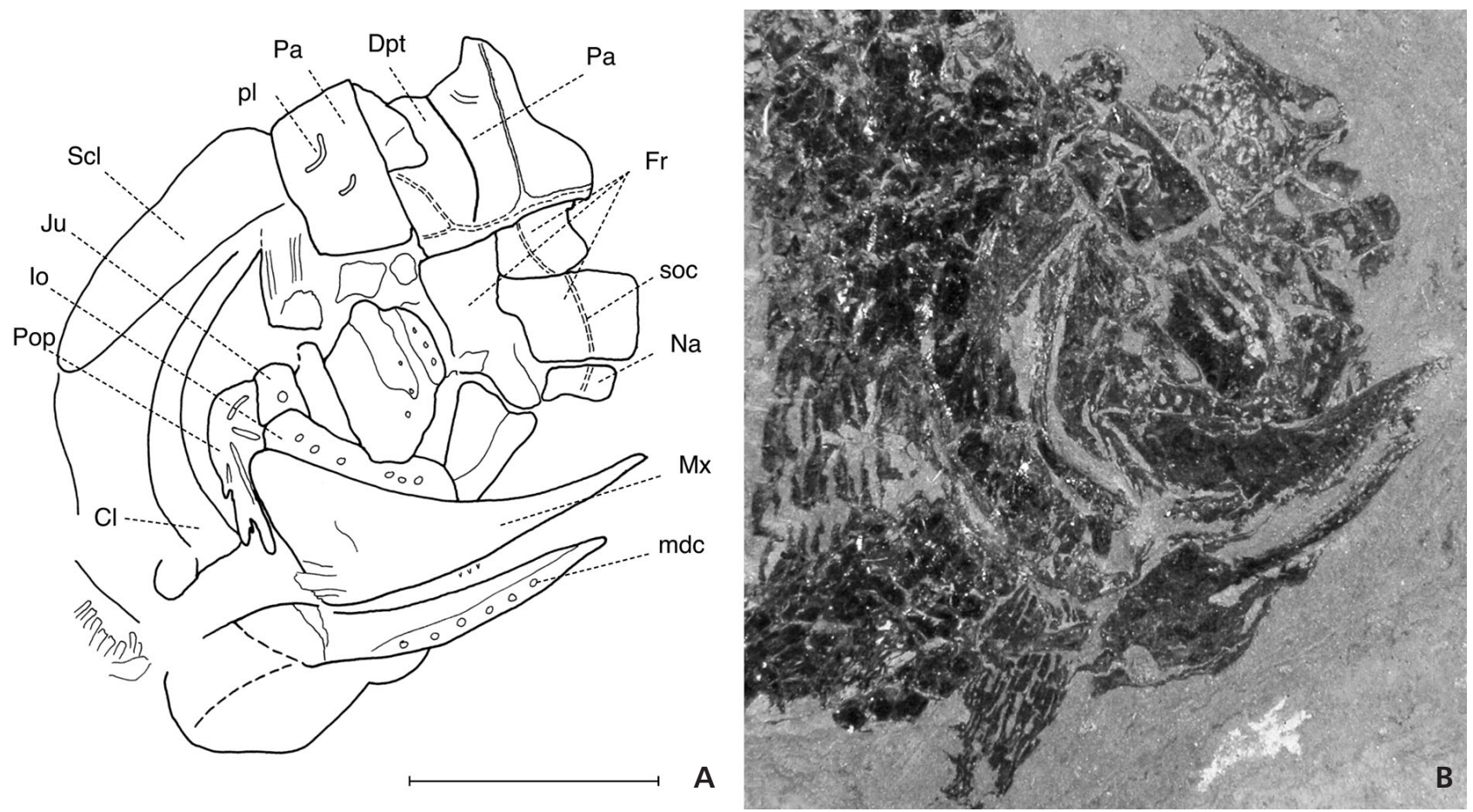

Figure 4. Neslovicella elongata sp. nov. • A - drawing and B - photograph (in alcohol) of the skull in lateral view, MHK 80458 . Scale bar represents $5 \mathrm{~mm}$. Abbreviations: $\mathrm{Cl}$ - cleithrum; Dpt - dermopterotic; Fr - frontal; Io - infraorbital; Ju - jugal; Mx - maxilla; mdc - mandibular canal; Na - nasal; $\mathrm{Pa}$ - parietal; Pop - preopercular; soc - supraorbital sensory canal; pl - pit line; Scl - supracleithrum.
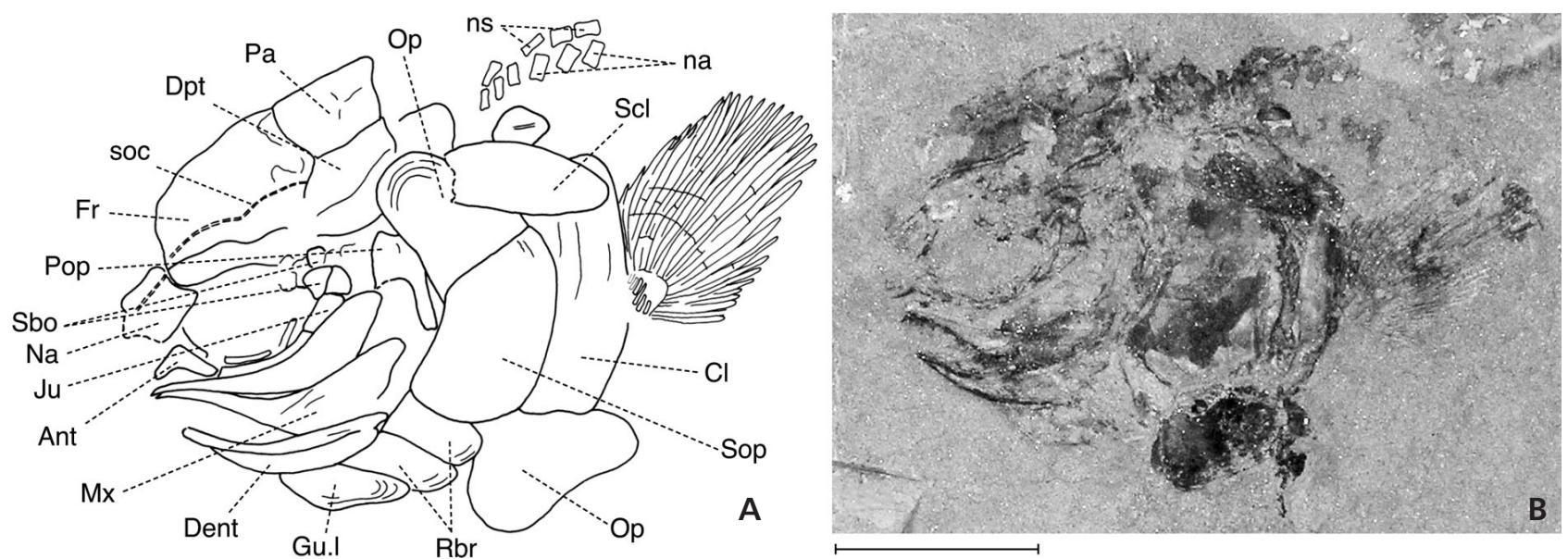

Figure 5. Neslovicella elongata sp. nov. • A - drawing and B - photograph (in alcohol) of the skull in lateral view, MHK 30744 . Scale bar represents 5 mm. Abbreviations: Ant - antorbital; Cl - cleithrum; Dent - lower jaw; Dpt - dermopterotic; Dsph - dermosphenotic; Fr - frontal; Gu.1 - lateral gular; Io - infraorbital; Ju - jugal; Mx - maxilla; mdc - mandibular canal; Na - nasal; na - neural arch; ns - neural spine; Op - opercular; Pa - parietal; Pop - preopercular; Rbr - branchiostegal rays; Sbo - suborbitals; soc - supraorbital sensory canal; Sop - subopercular; pl - pit line; Scl - supracleithrum.

The parietal is slightly elongate, relatively large compared to the frontal, but it is not as large as the frontal. Its precise outline is obscured in several specimens. This bone is preserved in MHK 80452 and MHK 80458 (Figs 2, 4). The frontal/parietal length ratio is about 1.1. This ratio is similar to that in Neslovicella rzehaki (Štamberg 2007a, p. 20). The frontal/parietal length ratio is 1.5 in Bourbonnella (Heyler 1969, Poplin 2001, Štamberg 2007a),
Aeduella and Decazella (Heyler 1969). The frontal in paramblypterids is twice as long as the parietal (Blot 1966; Štamberg 1976; Dietze 1999, 2000). The left and right parietals are often dissimilar. In some cases, the left parietal may appear slightly elongate, whilst the right one is almost square (MHK 80452; Fig. 2). The interparietal suture is straight and continuous with the interfrontal suture. The whole lateral margin of the parietal abuts the 
dermopterotic. The pit lines are well preserved in MHK 80458 (Fig. 4). The lateral and posterior pit lines meet in the latero-posterior area of the parietal forming a bowshaped pit line system. The remaining pit lines are indistinct, and can be observed in the central region of the parietal of the same specimen.

The preservation of the dermosphenotic and dermopterotic is usually poor, but partial preservation can be observed in MHK 80452 (Fig. 2). The dermosphenotic appears to be narrow and elongate anteroposteriorly. The dermopterotic is a large polygonal bone situated posterior to the dermosphenotic. No obvious traces of sensory canals could be observed on the dermopterotic. The extrascapulars form a narrow strip of bones along the posterior border of the skull roof, and establish a connection betveen the skull roof and the pectoral girdle, the latter being represented by the posttemporal posteriorly. MHK 80452 exhibits what appear to be two pairs of extrascapulars (Fig. 2). The larger pair is in contact with the parietal posteriorly, the smaller pair has contact with the dermopterotic posteriorly.

The cheek is poorly preserved. Although the maxilla is well known in several specimens, the circumorbital bones are almost unknown. The outlines of the orbits in MHK 80447, M 2705 and MHK 30744 are slightly elongate anteroposteriorly. The triangular antorbital and the long, narrow infraorbital are squeezed into the space between the orbit and maxilla. The strip of infraorbital bones continues with the jugal between the orbit and the posterior plate of the maxilla (Figs 4, 5). The infraorbital of MHK 80458 carries a line of six pores representing the infraorbital canal. The latter passes dorsally onto the jugal. The space between the orbit and the opercular was presumably filled with several small bones in life, but only three small suborbital bones are partially preserved in MHK 30744 (Fig. 5). A mosaic of small suborbital bones is also representative of Aeduella blainvillei (Heyler 1969, figs 92, 97), Bourbonnella hirsuta (Štamberg 2007, fig. 51), Neslovicella rzehaki (Štamberg 2007, fig. 23). This is one of the important characters of the Aeduellidae (Poplin \& Dutheil 2005). A similar mosaic of small suborbital bones is also present in paramblypterids (Blot 1966; Dietze 1999, 2000).

The orbit is delimited dorsally by the dermosphenotic. A small preopercular sits between the posterodorsal region of the maxilla and the anterior margin of the opercular and subopercular. The anterior margin of the dorsal half of the axe-shaped preopercular of MHK 80458 is vertically orientated. The ventral and posterior margins of the narrow region of this bone are markedly undulated. The preopercular abuts the posterior margin of the maxilla including the dorsal apex of the maxillary plate. The preopercular canal runs dorsoventrally along the anterior border of the narrow region of the bone. Two conspicuous pit lines on the dorsal region form a $\mathrm{V}$-shaped pattern with the apex of the $\mathrm{V}$ pointing posteriorly.
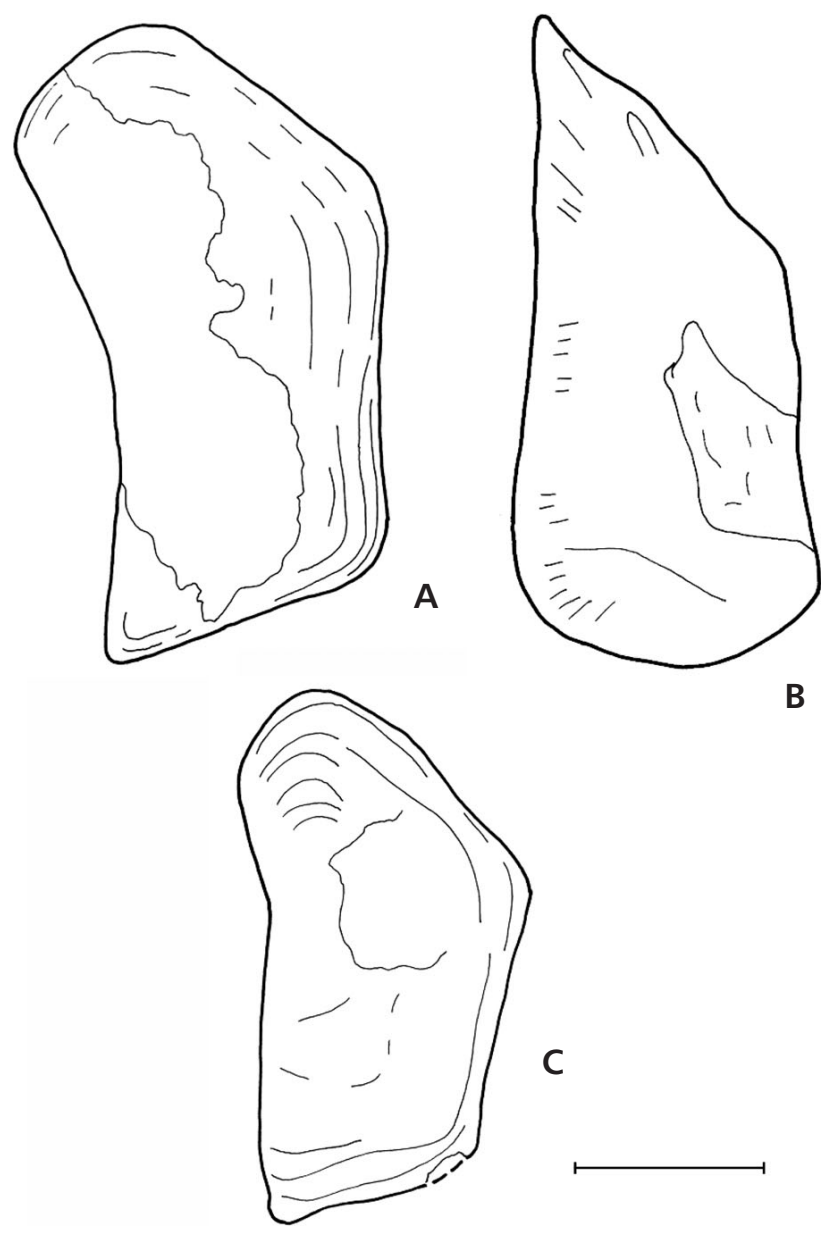

B

Figure 6. Neslovicella elongata sp. nov. • A - left opercular in lateral view, MHK 64733. • B - right subopercular in medial view, MHK 64733. - C - left opercular in lateral view, SaP 16. Scale bar represents $2 \mathrm{~mm}$.

The maxilla (Figs 3, 4) is anteriorly narrow, pointed, and slightly curved ventrally. The bone increases in height posteriorly forming a triangular maxillary plate. The dorsoposterior angle of the plate is rounded, whilst its posterior margin is straight or slightly concave. The length/height ratio of the maxilla is 2.2 in more mature specimens, and ranges from 2.4 to 3.4 in younger specimens (see section on ontogeny below).

The lower jaw is lightly built and slightly curved ventrally. It carries pores of the mandibular canal arranged in a line parallel to the ventral margin of the bone. Minute, slender and sharply pointed tubular teeth are on the lower and upper jaws. In MHK 80455, up to about 30 teeth were observed.

Opercular, subopercular, two branchiostegal rays and a gular lateral contribute to the opercular apparatus. The large, flat, oblong opercular is dorsoventrally elongate and twice as tall as it is long, with its dorsal region curving anteriorly. The axis of greater elongation of this bone forms an angle of about 60 degrees with the horizontal axis, and its 


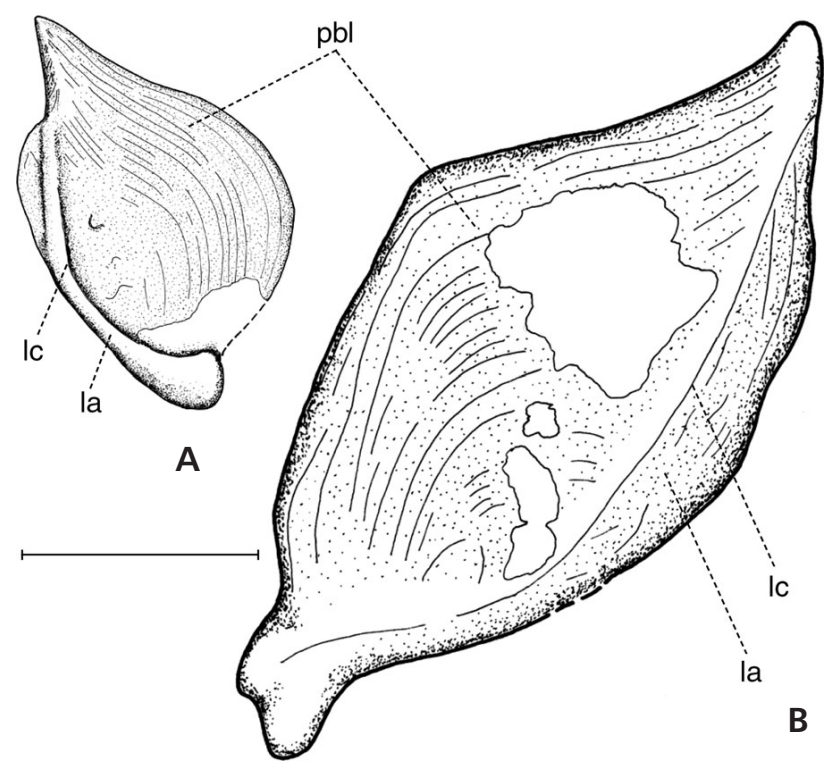

Figure 7. Neslovicella elongata sp. nov., counterpart of the left cleithrum of a very juvenile specimen, MHK 80450, in anterior view (A), and left cleithrum of adult specimen, MHK 64733, in anterior view (B). Scale bar represents $2 \mathrm{~mm}$. Abbreviations: la - lateral area; lc - lateral crest; pbl - postbranchial lamina.

anterior margin is curved at about 150-160 degrees (angle between the dorsal and ventral parts of the oral margin of the bone; Fig. 6A, C). The opercular contacts the dermopterotic dorsally, and its concave anterior margin accommodates the preopercular ventrally. No other bones adjacent to the opercular are preserved more anteriorly. The convex posterior margin of the opercular overlaps the supracleithrum and the cleithrum. The subopercular is dorsoventrally elongate and narrower than the opercular and exhibits a conspicuous posterodorsal process. Its dorsal margin slopes anteroventrally. Its anterior margin is 25 to 33 percent shorter than the posterior margin (Fig. 6B). The height of the subopercular, including its posterodorsal process, is twice its length, and comparable to the height of the opercular. The subopercular is overlapped by the opercular dorsally, and the suture between these two bones is conspicuously oblique.

The two short branchiostegal rays are usually poorly preserved, except in MHK 30744 (Fig. 5) and MHK 80457 , and occur ventral to the subopercular. A single pair of gular lateral bones, situated anterior to the branchiostegal rays (Fig. 5), can be clearly observed in MHK 30744 and MHK 30890. The small number of branchiostegal rays in N. elongata conforms to that of other aeduellids, and it is an important character of the whole family Aeduellidae. This small number of branchiostagal rays, between one and three, is an uncommon feature among the Carboniferous and Lower Permian actinopterygians. Usually the Haplolepidae possess one or none (Westoll 1944, Gardiner \& Schaeffer 1989), and Canobius (Moy Thomas \& Dyne
1938) has a reduced number of branchiostegal rays, nevertheless double that in comparison with the Aeduellidae.

\section{Pectoral girdle}

The pectoral girdle consists of the postemporal, supracleithrum and cleithrum. No clavicle has been preserved. The postemporal is poorly preserved, and cannot be fully described. The narrow supracleithrum of MHK 64733 is elliptical, dorsoventrally elongate, almost as tall as the opercular, and overlaps the dorsal process of the cleithrum. A sensory canal runs obliquely across the dorsal quarter of the external surface of the bone. More ventrally on this surface, tubercles and short ridges contribute to the external sculpturing of the supracleithrum.

The dorsoventrally elongate cleithrum is well preserved in several specimens. It is a relatively large bone of ovoid shape, reaching up to a quarter of the height of the opercular. The cleithrum is anteroventrally curved. A lateral crest divides the lateral surface of the bone into a narrower strip-like posterior area not overlapped by bones, and a wider leaf-shaped antero-medial area (postbranchial lamina) extensively overlapped by opercular, subopercular, and branchiostegal rays. The narrower area is covered with dorsoventral ridges, whereas the postbranchial lamina shows numerous concentrical lines mostly parallel to the medial margin of the bone. Such concentrical lines on the postbranchial lamina are a diagnostic feature of aeduellid actinopterygians (Fig. 7A, B). The same sculpture on the postbranchial lamina occurs in Neslovicella rzehaki, Bourbonnella hirsuta, Spinarichthys dispersus and Aeduella blainvillei (personal observation). The cleithrums of $N$. elongata occur in the same strata as cleithrums of Paramblypterus. These bones in N. elongata are clearly distinguishable due to their ovoid shape, concentrically arranged lines on the anteromedial branch and less conspicuous sculpture on the lateral side of the cleithrum.

\section{Axial skeleton}

The morphology of the vertebral column and the endoskeleton of the anal fin are best observed in MHK 30744 (Figs 5, 8). Parts of the vertebral column are preserved in the anterior and caudal regions of the body. The anterior region displays six neural arches of oblong shape moderately elongated dorsoventrally. Five ossifications of oblong shape orientated predominantly anteroposteriorly are joined to the neural arches dorsally (Figs 5, 8). These ossifications are interpreted as neural spines. Poorly preserved stick-like ossifications of the neural arches are found anteriorly to the dorsal fin. 


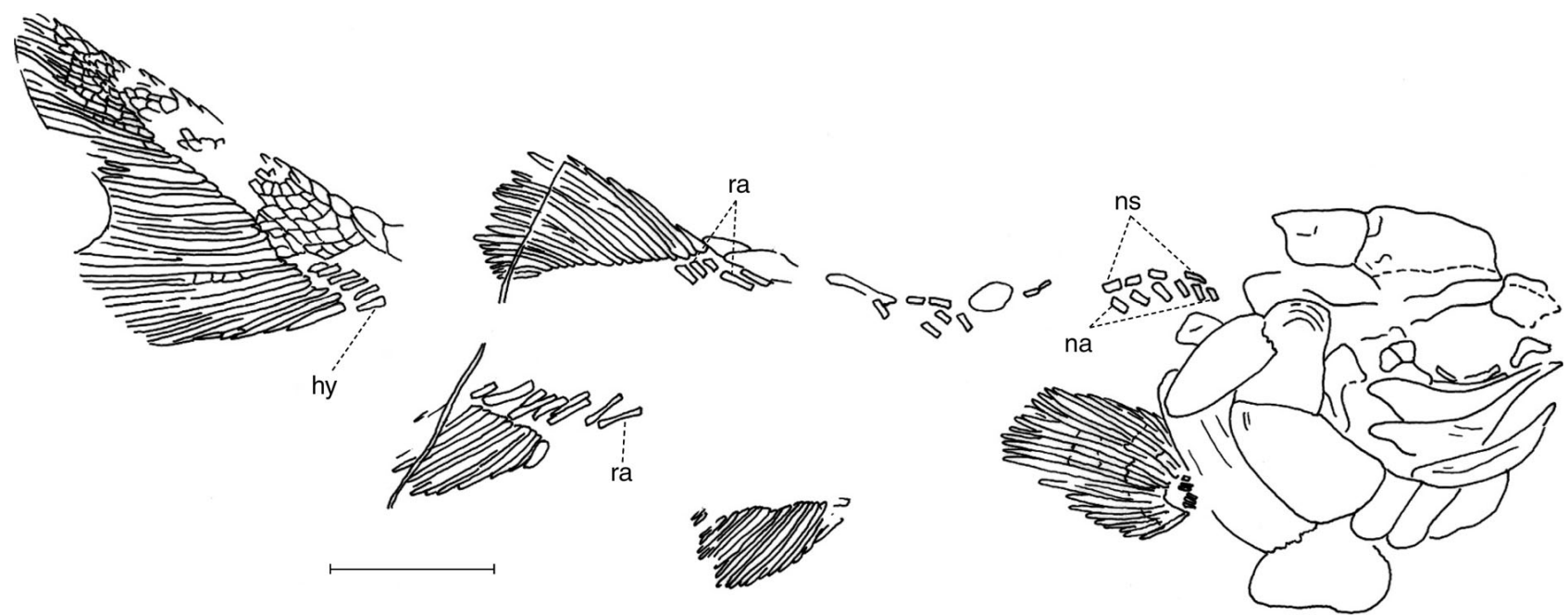

Figure 8. Neslovicella elongata sp. nov., young specimen without squamation, and with partly preserved axial skeleton, MHK 30744 , features of the part and counterpart are drawn in one figure. Scale bar represents $5 \mathrm{~mm}$. Abbreviations: hy - hypural; na - neural arch; ns - neural spine; ra - radial.

Stick-like elements of the neural arches are also known in Sceletophorus biserialis Fritsch, 1894 (Štamberg 1983, pl. 2, fig. 2). The neural arches in Pteronisculus (Nielsen 1942, fig. 50) have a proximal plate and a long distal process; similar shaped paired neural arches occur in Mimia toombsi Gardiner \& Bartram, 1977 (Gardiner 1984, figs 121, 123, 124) and Kalops diophrys Poplin \& Lund, 2002 (Poplin \& Lund 2002, fig. 7).

MHK 30744 shows six or seven stick-like hypurals orientated diagonally relative to the horizontal plane (Fig. 8). They are joined at the base of the ventral lobe of the caudal fin. The anterior hypural is $1.5 \mathrm{~mm}$ long, and the more posterior hypurals become progressively shorter.

The endoskeleton of the anal fin contains nine rodshaped radials (Fig. 8) which become wider both proximally and distally. The anteriorly directed radials are arranged in a single row, orientated obliquely relative to the horizontal axis. The anal fin of Sceletophorus biserialis is supported by 12 to 14 rod-shaped radials arranged in one row (Štamberg 1983, fig. 6), while Mimia toombsi has seven long radials, expanded distally, and a single radial plate posteriorly (Gardiner 1984, fig. 124). The series of eleven radials of the anal fin of Pteronisculus contains two ossifications arranged in two rows (Nielsen 1942, figs 50, 56). The proximal ossifications are long, whereas the distal ones are very short.

The radials along the base of the dorsal fin are poorly preserved on MHK 30744 and SaP 752. They are arranged in two rows but their shape and connections are not clearly exposed (Fig. 8).

\section{Paired fins}

The pectoral fin is situated relatively low on the flank, posterior to a shallow notch in the cleithrum. The pectoral fin resembles a fan with the leading edge orientated dorsoanteriorly. The specimen MHK 30744 (Fig. 5A, B) illustrates its basic morphology. The proximal region of the pectoral fin is formed by six rod-shaped radials, although these are not well exposed. Observation of other specimens indicates the presence of a small scaly lobe near the fin base. Twenty-eight lepidotrichia arranged in a fan-shaped pattern connect to the radials in MHK 30744. The lepidotrichia are segmented along their whole length, and subdivided distally. The longest lepidotrichia consists of more than 10 segments. The five anteriormost lepidotrichia extend to the leading edge of the fin and terminate as spine like structures in combination with the fringing fulcra.

The longest lepidotrichia of the pectoral fin in the young specimen MHK 30744 (Fig. 5) form the anterior half of the pectoral fin while the longest lepidotrichia of the adult specimens MHK 80456 and MHK 19810, concentrate near to the leading edge of the pectoral fin. Dissimilarities in the shape of the pectoral fin are probably not a question of ontogeny, but they are caused by imperfect preservation of the terminal parts of the lepidotrichia in young specimens. Fringing fulcra are rare in the young specimens. They are more numerous in the adult specimens, but not so plentiful as in Paramblypterus, Rhabdolepis, Elonichthys and many other taxa. The leading edge of the pectoral fins are not well preserved on the specimens, but pattern B fringing fulcra (Arratia 2009) can be observed, similarly to those occurring in other aeduellids [(Neslovicella rzehaki, Bourbonnella hirsuta (Štamberg 2007a), Aeduella blainvillei (Heyler 1969)].

The pelvic fin is situated behind the ninth row of trunk scales, halfway between the posterior margin of the cleithrum and anterior insertion point of the anal fin. The pelvic fin contains 13 or 15 segmented lepidotrichia (MHK 80447, MHK 30744, MHK 80459) consisting of at least 10 long segments. 


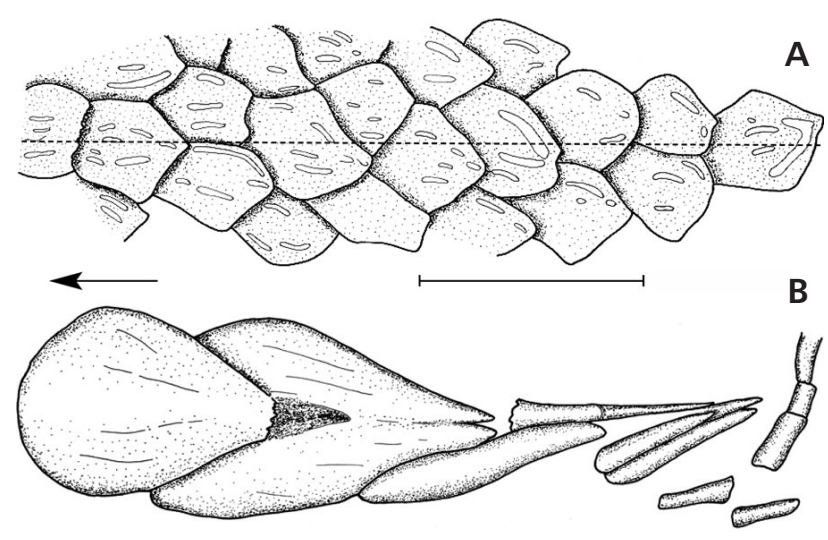

Figure 9. Neslovicella elongata sp. nov. $\bullet$ A - scales on the dorsal crest of the body posteriorly to the skull in MHK 64836. Dashed line indicates the medial body ridge. $\bullet \mathrm{B}$ - ridge scales anteriorly to the dorsal fin on MHK 64732. The arrow indicates directio cranialis, scale bar represents $2 \mathrm{~mm}$.

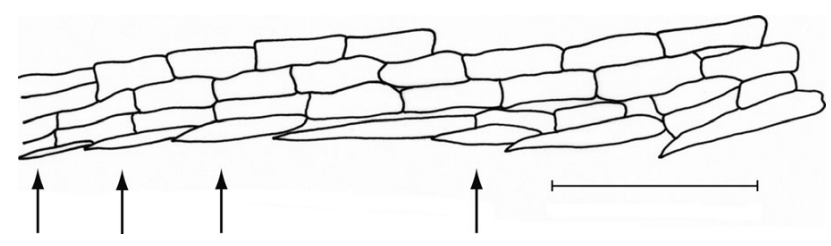

Figure 10. Neslovicella elongata sp. nov., section of the leading edge of the ventral lobe of the caudal fin. Lepidotrichia terminate as spine like structures in combination with the fringing fulcra (arrows). MHK 64733, scale bar represents $2 \mathrm{~mm}$.

The segments are approximately three times longer than wide. Fringing fulcra are present on the leading edge of the pelvic fin. In adult specimens, the length of the pelvic fin base is about half the length of the anal fin base, but in juvenile specimens it is relatively longer, attaining up to four-fifths the length of the anal fin base (MHK 30897).

\section{Unpaired fins}

The anal fin is slightly smaller than the dorsal fin, and situated posterior to the twenty-fourth row of the trunk scales, in a position corresponding dorsoventrally to the level of the posterior margin of the dorsal fin base. The base of the anal fin extends over the length of seven or seven and a half scale rows. The anal fin contains approximately 18 segmented lepidotrichia, subdivided distally. The longest lepidotrichia consist of 10-12 segments and those that reach the leading edge of the fin terminate as spine like structures in combination with the fringing fulcra.

The dorsal fin is approximately triangular and situated posterior to the twenty-sixth row of trunk scales, approximately in the middle of the total body length. It carries about 20 segmented lepidotrichia, subdivided distally. Up to 10-12 slender, elongate segments were observed. The leading edge of the dorsal fin is protected by terminal segments in combination with the fringing fulcra.

The caudal fin is attached to an elongate and slender caudal peduncle. It is distinctly inequilobate and deeply cleft, its dorsal lobe being longer than its ventral lobe. The dorsal/ventral lobe length ratio is approximately 1.5. The axis of the dorsal lobe forms an angle of 20-25 degrees with the horizontal body axis (MHK 80447, MHK 64836, MHK 80451), and an angle of about 40 degrees with the axis of the ventral lobe. The dorsal lobe is covered with rhombic scales, and long fulcral scales occur along its entire dorsal margin. The dorsal lobe consists of approximately 45 lepidotrichia, the longest of which is divided into nine or ten segments (MHK 80447). The ventral lobe has 16-17 lepidotrichia (MHK64837, MHK 80447, MHK 80453 ), the longest of which consists of 12 segments. The leading edge of the ventral lobe is protected by terminal segments in combination with the fringing fulcra (Fig. 10).

\section{Squamation}

Scales are well preserved in most specimens. The scale count is recorded from 11 specimens (Table 1). Scale row numbers vary widely depending upon the degree of deformation. The total range of scale count of all specimens studied in the present work is as follows:

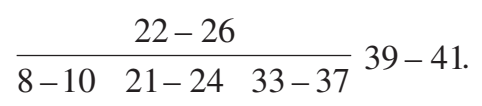

The scale count that probably comes closest to the actual state was established mainly on the basis of measurements in the holotype and in two other well preserved specimens (MHK 80149, MHK 64732), and using arithmetic means where appropriate:

$$
\frac{26}{9 \quad 24 \quad 36} 40 \text {. }
$$

The shape and ornamentation of the scales are highly variable depending upon their location on the trunk and the age of the specimen. The scales that carry the lateral sensory line exhibit a distinctive morphology. They are the largest of all the flank scales, with a strongly pectinate posterior margin (Fig. 11A, B). The vaulting of their central surface and the presence of an incision along their posterior margin mark the course of the lateral sensory line. The latter extends from the supracleithrum to the apex of the angle delimited by the dorsal and ventral lobes of the caudal fin. The oblong flank scales in the anterior region of the trunk are posteriorly pectinated. This pectinate pattern becomes less distinctive and gradually disappears in posterior, dorsal and ventral directions, and the shape of the scales changes from oblong to rhombic. Scales occurring at the level of the anterior insertion of the anal fin bear only one 
or two minute denticles on the ventral part of their posterior margin (Fig. 11B). A pectinate pattern is absent on the scales occurring posterior to the anal fin. The lateral surface of the scales is smooth except in the dorsal region of the anterior part of the body, where the scales carry fine, anterior-posteriorly orientated ridges. Dorsally, the scale rows from the right and left sides of the flank meet at an unpaired scale row (Fig. 9A).

Three large ridge-like scales are present anterior to the dorsal fin (Fig. 9B), and a pair of large scales occurs anterior to the anal fin. The dorsal lobe of the caudal fin is covered by a series of long fulcral scales which begin at the level of the anterior edge of the lobe squamation. The caudal inversion is abrupt.

\section{Ontogeny}

A survey of specimens with body length between 28 and $75 \mathrm{~mm}$ provided the basis for a study of changes during growth, both at the level of specific bones and at the level of overall body proportions. Here, the focus is on modifications of the maxilla, fins, and body squamation, as these structures are particularly prone to ontogenetic variation.

\section{Maxilla}

The shape and proportions of the maxilla undergo remarkable changes during ontogeny. In adult specimens, the maxilla has an almost straight ventral margin, and is slightly curved ventrally at its anterior extremity. Its length/height ratio is about 2.2. In juvenile specimens, the maxilla has an undulate ventral margin sloping dorsoposteriorly along its posterior tract (Fig. 3A). In the same specimens, the low triangular maxillary plate is conspicuously concave posteriorly, and the length/height ratio of the bone is 3-3.4. The overall shape of the maxilla in juvenile specimens is comparable to that of aeduellids from Buxières-les-Mines figured by Heyler (1969, figs 126 D, $156 \mathrm{G})$.

\section{Fins}

The relative positions of the fins do not change with growth. In this respect, Neslovicella elongata sp. nov. conforms to the pattern exhibited by Aeduella blainvillei (Heyler 1969, p. 157). However, changes can be documented in the relative proportions of both paired and unpaired fins. Thus, juvenile specimens have well developed paired fins. In MHK 30897 (Fig. 13A), the pelvic fin is as large as the anal fin, but in the larger MHK 30744 (Fig. 8), the anal fin is slightly larger than the pelvic fin. In adult specimens, the base of the anal fin is twice as long as the base of the pelvic fin. Remar-

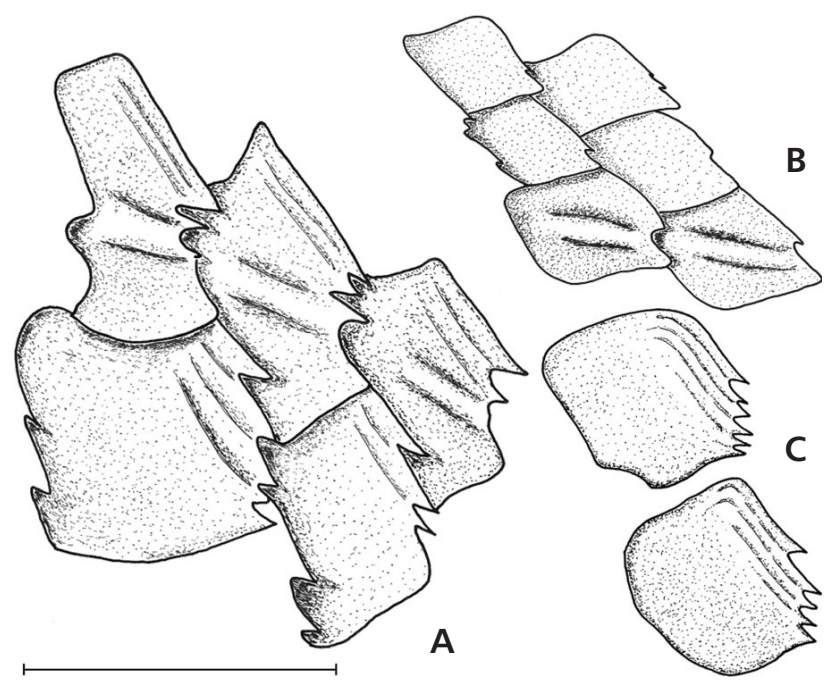

Figure 11. Neslovicella elongata sp. nov. $\bullet$ A - scales with lateral sensory line and flank scales from rows 9-11, MHK 64846. • B - scales with lateral sensory line and flank scales from rows 28-29 from the same specimen. $\bullet \mathrm{C}$ - pectinated flank scales from the tenth row, MHK 64732. Scale bar represents $2 \mathrm{~mm}$.

kable changes are also seen in the caudal fin. Thus, in the juvenile MHK 30897 (Fig. 13A) the caudal fin already exhibits well-developed lepidotrichia and is of sturdy appearance. However, the dorsal and ventral lobes are only vaguely distinct due to the lack of a deep incision between them, unlike the situation observed in larger specimens.

Although the number of fin lepidotrichia does not appear to vary, the number of segments in each lepidotrichium increases during growth. A precise count of these segments is only possible in few specimens. In younger specimens MHK 64730 and MHK 30744, eight segments make up the longest lepidotrichia of the anal and dorsal fins. In older specimens MHK 64733, MHK 64732 (and others), 12 segments have been recorded in the same fins. The lepidotrichial segments of all fins are elongate both in young and adult specimens.

\section{Squamation}

The youngest specimen (MHK 30897: total length $28 \mathrm{~mm}$ ) shows no squamation on the flanks neither lateral line scales nor ridge-like scales. Scales develop initially on the dorsal lobe of the caudal fin (MHK 30897, MHK 64730). In MHK 30744 (Fig. 8)and MHK 30890, which both have a total length of about $50 \mathrm{~mm}$, there are scales and fulcral scales on the dorsal lobe of the caudal fin, a ridge-like scale anterior to the dorsal fin, and a large scale anterior to the anal fin, but no other squamation is developed. A complete set of scales is observed in M 2718 (total length: $34 \mathrm{~mm}$ ) and M 2710 (total length: $48 \mathrm{~mm}$ ), although the scales are thin. The squamation is well developed on all specimens 


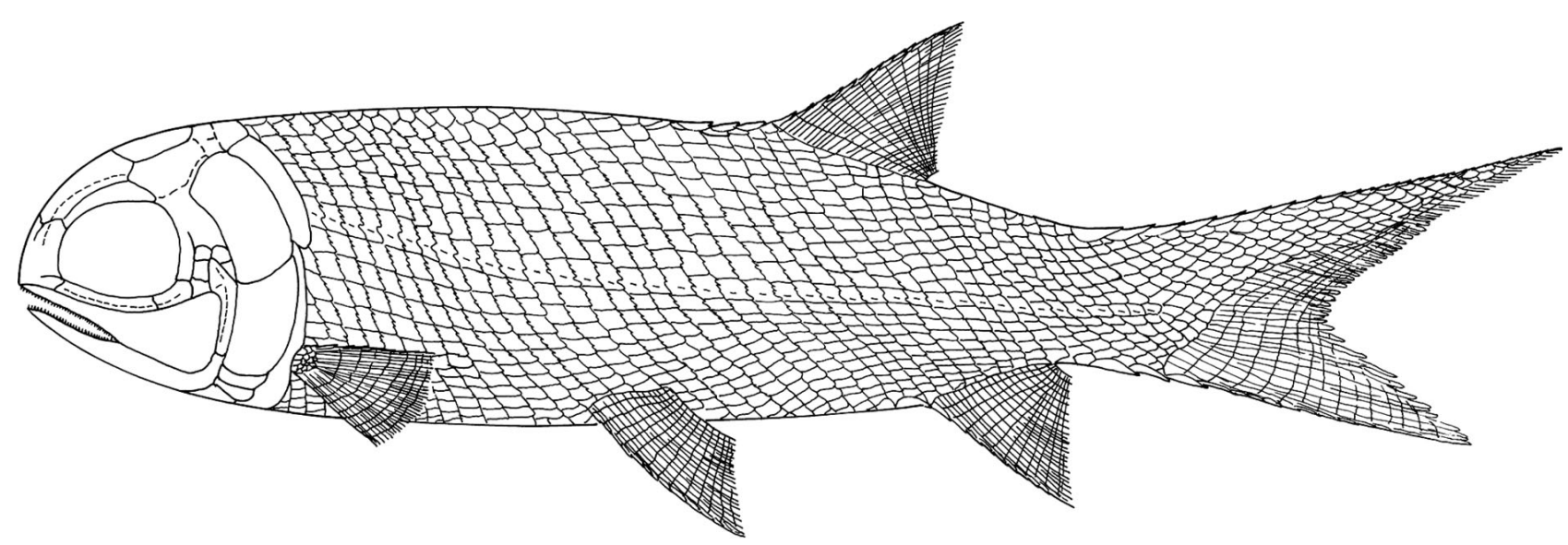

Figure 12. Neslovicella elongata sp. nov. Restoration of the skull and the body, $\times 2.5$.

exceeding $55 \mathrm{~mm}$ in total length. The pattern of scale development conforms to that documented by Štamberg (1983, pp. 60, 61) in Sceletophorus biserialis.

Based on the ontogenetic data illustrated above, specimens measuring $60 \mathrm{~mm}$ and above in total length are regarded as adults.

\section{Stratigraphic and geographical records of Neslovicella elongata}

Most specimens (22) of Neslovicella elongata sp. nov. come from Koštálov ("Behind the Tavern"), whereas extensive fieldwork in other localities has yielded very few specimens. At present, it is not possible to ascertain whether this discrepancy reflects sampling bias or genuine abundance of this taxon at Koštálov. Interestingly, species assemblages are very similar in all collecting localities, and consist of conchostracans, acanthodians, elasmobranchs, and actinopterygians, the latter including the genus Paramblypterus (Štamberg \& Zajíc 2008). Sedimentological characteristics are also comparable in all localities (Martínek et al. 2006).

The occurrence of Neslovicella elongata at Weissig near Dresden (Germany) is interesting. Three specimens from this locality were found by the author in the collections of the Museum für Mineralogie und Geologie, Dresden. The Weissig locality is in the Weissig Basin (Schneider \& Reichel 1989, Schneider \& Werneburg 2006), and is assigned to the Weissig Formation, Lower Permian (Schneider et al. 2005). The Neslovicella elongata-bearing beds of the Weissig Formation and Rudník Horizon might be of identical age, and document the existence of a drainage system connecting the Krkonoše Piedmont Basin in the Bohemian Massif and the Weissig Basin in Germany. Furthermore, in the Lower Permian interconnected fluvial and lacustrine systems were dotted around the
Elbe lineament in Germany and Bohemia. Schneider et al. (2005) and Schneider \& Werneburg (2006) distinguished the different layers of the Weissig Formation on the basis of the occurrence of the insect Sysciophlebia weissigensis, and use this species for biostratigraphical correlations across different basins in Europe, including the Ríčany Horizon in the Boskovice Graben (Bohemian Massif). Note that fossil insects have not been recorded in the Rudník Horizon, but the age of the latter can be established in the light of the actinopterygians and other faunistic elements present.

\section{Discussion}

Neslovicella elongata sp. nov. is another new species of Aeduellidae supporting their wide geographical distribution in the European Permocarboniferous basins. The diagnosis of Neslovicella clearly indicates that this genus belongs to the family Aeduellidae. Features that are diagnostic for the family (Heyler 1969, Poplin \& Dutheil 2005 ) include: mosaic of suborbital bones; presence of tubular teeth along the upper and lower jaws; small preopercular not reaching the skull roof; interconnection of the supraorbital and infraorbital canals on the dermopterotic; penetration of the supraorbital canal on the dermopterotic in the form of a pit line. To this list, three further features can be added: triangular shaped maxilla, tall opercular, cleithrum with wide postbranchial lamina with numerous concentrical lines mostly parallel to the medial margin.

A close relationship between Neslovicella and Aeduella Westoll, 1937 can be established on the basis of the following characters: shape of maxilla; shape of opercular including its anteriorly curved dorsal region; very tall subopercular; construction of cheek; large orbit; course of supraorbital sensory canal; lobate scaly base of pectoral 

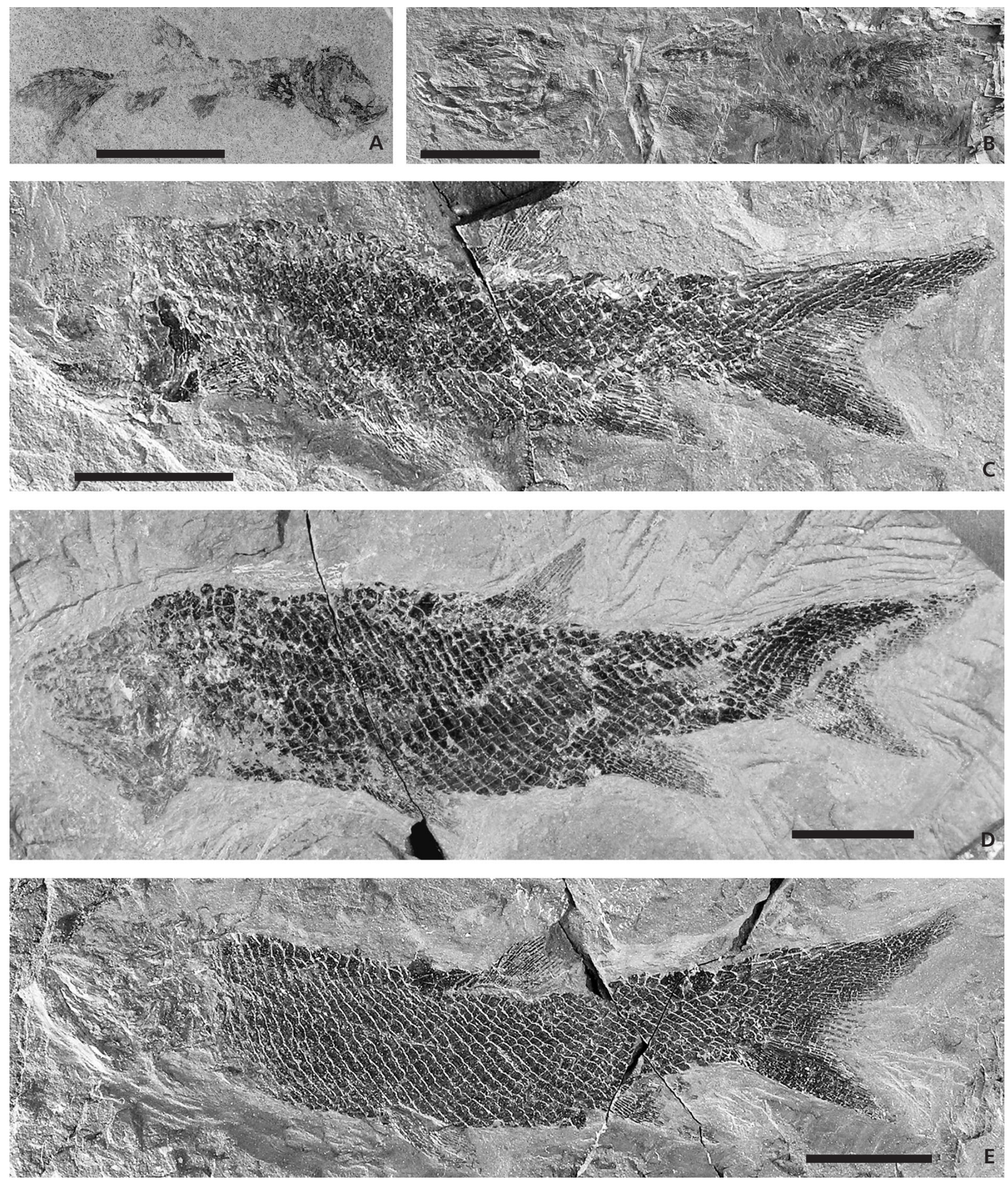

Figure 13. Neslovicella elongata sp. nov. Scale bars represent 10 mm. • A - MHK 30897 (in alcohol); B - MHK 30890; C - holotype MHK 80447 (in alcohol); D - MHK 81372; E - MHK 80451.

fin; general position of fins. However, several morphological and growth features distinguish Neslovicella from Aeduella: Both species of Neslovicella represent very small fishes not exceeding $103 \mathrm{~mm}$ in total body length. In contrast, Aeduella reaches $200 \mathrm{~mm}$ in body length. The triangular shaped maxilla has a length/height ratio between 
2.4 to 3.4 in Neslovicella, and from 3 to 4 in Aeduella blainvillei. The opercular-subopercular suture is oblique in both genera, but it shows an undulated course in Aeduella. In Neslovicella the scales are pectinated along their posterior margin, but not in Aeduella. The differences between the two genera are also evident in the configuration of the snout, but the poor preservation of this region in N. elongata prevents a discussion of this feature.

Similar body outlines are shared by both Neslovicella and Spinarichthys (Štamberg 1986). Spinarichthys, represented by Spinarichthys dispersus (Fritsch, 1895), occurs in the Upper Carboniferous sediments of the Bohemian Massif. It possesses several features, which are typical for Aeduellidae.

Close similarities between Neslovicella and Spinarichthys include a short head, large orbit, maxilla with triangular shape, preopercular in vertical position, opercular and subopercular very tall, small number of branchiostegal rays, and posteriorly pectinated scales. The differences between the two genera are in the shape of the posterior region of the maxilla (the maxilla of Neslovicella gradually increases in height posteriorly whereas the maxilla of Spinarichthys increases suddenly in height and forms a triangular maxillary plate posteriorly), branchiostegal rays (two branchiostegal rays of the same size in Neslovicella, but three branchiostegal rays in Spinarichthys, of which the first one, under the subopercular, is markedly taller than the other two), the suture between the opercular and subopercular (an oblique straight suture in Neslovicella, in contrast an undulating suture in Spinarichthys), squamation (posterior border of the scales of Neslovicella are pectinated, but not so conspicuously as in Spinarichthys, plus long slender processes of the peg and socket articulation in Spinarichthys), stratigraphical range (Neslovicella occurs in the Lower Permian of the Krkonoše Basin and Boskovice Graben, Spinarichthys is restricted to the Upper Carboniferous of the Krkonoše Piedmont Basin and the basins of the Central and Western Bohemian Area).

Characteristic features of Aeduella are mentioned in the sense of Heyler (1969) in this report. Gardiner \& Schaeffer (1989, fig. 18D) published a reconstruction of Aeduella blainvillei with a note, suggesting that it is after Heyler (1969) and specimen BM(NH) P.30034. The reconstruction of Aeduella blainvillei according to Gardiner \& Schaeffer's (1989) interpretation is misleading in the region of the cheek (preopercular very tall reaching as far as the dermopterotic, absense of the mosaic of small bones between the preopercular and the orbit). This reconstruction is fundamentally different from the excellent reconstruction by Heyler (1969, fig. 92). Heyler (1969) figured the important cheek region of the type specimen in several high quality ink drawings (specimen deposited in the collection of the University of Strasbourg under
No. VP $1118=$ Heyler's number St 1), as well as the cheek of other well preserved specimens deposited in the Muséum National d'Histoire naturelle in Paris. Regarding specimen $\mathrm{BM}(\mathrm{NH})$ P.30034 cited by Gardiner \& Schaeffer (1989) and deposited in the Natural History Museum, London, it actually shows the partly preserved bones of the skull roof, but nothing connected with the cheek bones.

The new species described here is obviously a member of the genus Neslovicella, as the diagnosis shows. Differences between $N$. rzehaki and N. elongata can be summarised as follows.

Neslovicella rzehaki: Body elevated-fusiform; total body length 3.3 times the body height; total body length up to $103 \mathrm{~mm}$; small field of minute scales present along the base of the dorsal and anal fins; caudal peduncle short; very small preopercular with oblique anterior margin in the wide dorsal region; subopercular taller than opercular; scale count

$$
\frac{22}{8 \quad 21 \quad 33} 36 .
$$

Neslovicella elongata sp. nov.: Slender body; total body length 5.1 times the tallest part of the body; total body length up to $75 \mathrm{~mm}$; absence of field of minute scales along the base of the dorsal and anal fins; caudal peduncle long; very small preopercular with vertical anterior margin in the wide dorsal region; subopercular and opercular of equal height; scale count

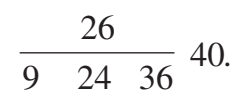

\section{Conclusions}

The occurrence of Neslovicella elongata sp. nov. from the Lower Permian of the Krkonoše Piedmont Basin (Bohemian Massif) adds to our knowledge of the distribution and diversity of the actinopterygian family Aeduellidae. This small fish is closely related to Aeduella but its morphology is distinct enough from that of the type species, $N$. rzehaki, to warrant specific separation.

The new species occurs in several localities of the Rudník Horizon and forms a substantial component of the fauna together with conchostracans, acanthodians, elasmobranchs, and actinopterygians of the genus Paramblypterus. Records from the Weissig Basin in Germany indicate that $N$. elongata sp. nov. was not restricted to only a few basins. The new species provides evidence for the existence of a drainage system between the Krkonoše Piedmont Basin in the Bohemian Massif and the Weissig Basin in Germany, as well as for Lower Permian interconnected fluvial and lacustrine systems along the Elbe lineament in Germany and Bohemia. 


\section{Acknowledgements}

This study is part of research project DE06P04OMG003, supported by the Ministry of Culture of the Czech Republic. I thank Martin Lapacík from Turnov for donating his own collection to the Museum of Eastern Bohemia. I am obliged to Ulf Linnemann and Ronald Winkler (Museum für Mineralogie und Geologie, Dresden), Boris Ekrt (National Museum, Prague), and Ortwin Schultz (Naturhistorisches Museum, Wien) for access to material in their care. Special thanks go to Cécile Poplin (Muséum National d'Histoire naturelle, Paris), Martha Richter (Natural History Museum, London), Marcello Ruta (University of Bristol), Andrea Tintori (Università di Milano) and an anonymous reviewer for many valuable comments and correction of the English. Thanks are also due to my daughter, Olga Čermáková, for the arrangement of illustrations.

\section{References}

AgASsIZ, L. 1833. Recherches sur les Poissons fossiles. Volume 2. 336 pp. Imprimerie de Petitpierre, Neuchâtel.

ARRATIA, G. 2004. Mesozoic halecostomes and the early radiation of teleosts, 279-315. In ARrATIA, G. \& TinTORI, A. (eds) Mesozoic Fishes 3 - Systematics, Palaeoenvironments and Biodiversity. Dr. Friedrich Pfeil Verlag, München.

ARRATIA, G. 2009. Identifying patterns of diversity of the actinopterygian fulcra. Acta Zoologica (Stockholm), 90 (Suppl. 1), 220-235. DOI 10.1111/j.1463-6395.2008.00375.x

Blecha, M., MARTíneK, K. \& MihaJleviČ, M. 1999. Paleoenvironmental changes of the semipermanent Kalná Lake (Lower Permian), Krkonoše Piedmont Basin, Czech Republic: sedimentary and geochemical record. Acta Universitatis Carolinae, Geologica 43(4), 657-665.

Blot, J. 1966. Étude des Palaeonisciformes du Bassin Houiller de Commentry (Allier, France). 99 pp. Cahiers de Paléontologie, Édition du Centre National de la Recherche Scientifique, Paris.

BÜRGIN, T. 1990. Palaeonisciden (Osteichthyes: Actinopterygii) aus dem Unteren Rotliegenden (Autunien) der Nordschweiz. Eclogae Geologicae Helvetiae 83(3), 813-827.

COPE, E.D. 1877. On the classification of the extinct fishes of the lower types. Proceedings of the American Association for the Advancement of Science 26, 292-300.

DIETZE, K. 1999. Paramblypterus duvernoyi (Actinopterygii): Skull, morphology and intra-specific variation, and its implications for the systematics of paramblypterid fishes. Journal of Vertebrate Paleontology 19(2), 247-262.

DIETZE, K. 2000. A revision of paramblypterid and amblypterid actinopterygians from Upper Carboniferous-Lower Permian lacustrine deposits of Central Europe. Palaeontology 43(5), 927-966. DOI 10.1111/1475-4983.00156

FOREY, P.L. \& YOUNG, V.T. 1985. Upper Stephanian fishes from the Puertollano Basin, Ciudad Real, Spain. Papers on the Carboniferous Iberian Peninsula (Sedimentology, Stratigraphy, Paleontology, Tectonics and Geochronology). Anais da Faculdade de Ciências do Porto 64, 233-244.

FRITSCH, A. 1895. Fauna der Gaskohle und der Kalksteine der Permformation Böhmens. Band 3, Heft 4, 105-132. F. Řivnáč, Praha.
GARDINER, B.G. 1960. A revision of certain Actinopterygian and Coelacanth fishes, chiefly from the Lower Lias. Bulletin of the British Museum (Natural History), Geology series 4, 241-384.

GARDINER, B.G. 1984. The relationships of the palaeoniscid fishes, a review based on new specimens of Mimia and Moythomasia from the Upper Devonian of Western Australia. Bulletin of the British Museum (Natural History), Geology series 37(4), 173-428.

GARDINER, B.G. \& BARTRAM, A.W.H. 1977. The homologies of ventral cranial fissures in osteichthyans, 227-245. In ANDREWS, S.M., MILES, R.S. \& WALKER, A.D. (eds) Problems in Vertebrate Evolution. Academic Press, London.

GARDINER, B.G. \& SCHAEFFER, B. 1989. Interrelationships of lower actinopterygian fishes. Zoological Journal of the Linnean Society $97,135-187$.

DOI 10.1111/j.1096-3642.1989.tb00550.x

GOTTFRIED, M.D. 1987. A Pennsylvanian aeduelliform (Osteichthyes, Actinopterygii) from North America with comments on aeduelliform interrelationships. Paläontologische Zeitschrift 61(1/2), 141-148.

GRANDE, L. \& BEMIS, W. 1998. A comprehensive phylogenetic study of amiid fishes (Amiidae) based on comparative skeletal anatomy. An empirical search for interconnected patterns of natural history. Journal of Vertebrate Paleontology 18(1), supplement Memoirs (1-4), 1-690.

HEYLER, D. 1964. A propos de quelques Vertébrés fossiles de l'Autunien (?) de Decazeville. L'Eduen Bulletin de la Société d'Histoire Naturelle d'Autun 31, 6-14.

HEYLER, D. 1967. Quelques points nouveaux au sujet d'Aeduella Westoll. Colloques Internationaux du CNRS 163, 81-88.

HEYLER, D. 1969. Vertébrés de l'Autunien de France. 255 pp. Cahiers de Paléontologie, Éditions du Centre National de la Recherche Scientifique, Paris.

HEYLER, D. 1977. Sur Bourbonnella sottyi, un nouvel Aeduellidae (poisson Actinoptérygien). Stéphanien du Bassin de BlanzyMontceau. Compte Rendu sommaire de la Société Géologique de France 1, 21-23.

HEYLER, D. 1991. Sur la présence de l'espèce Aeduella blainvillei (Pisces, Actinopterygii) dans le Permien Inférieur de la Sarre. Bulletin de la Société d'Histoire Naturelle d'Autun 135, 17-32.

HEYLER, D. 2000. Les actinoptérygiens Stéphaniens et Autuniens du Massif Central (France) dans les collections du M.N.H.N. (Paris) et du Muséum d'Autun: compléments, mises au point, bilan. Bulletin de la Société d'Histoire Naturelle d'Autun 169, $7-44$.

HEYLER, D. 2002. Inventaire des Vertébrés de l'Autunien de Bourbon-l'Archambault (Allier) dans les collections du MNHN (Laboratoire de Paléontologie) et un nouveau Platysella. Revue Scientifique du Bourbonnais, 17-40.

HEYLER, D. \& POPLIN, C. 1983. Actinoptérygiens du Stéphanien de Montceau-les-Mines (Saône-et-Loire, France). Palaeovertebrata 13, 33-50.

MartíneK, K., Blecha, M., DanĚK, V., Franců, J., HladíKOVÁ, J., JOHNOVÁ, R. \& ULIČNÝ, D. 2006. Record of palaeoenvironmental changes in a Lower Permian organic-rich lacustrine succession: Integrated sedimentological and geochemical study of the Rudník member, Krkonoše Piedmont Basin, Czech Republic. Palaeogeography, Palaeoclimatology, Palaeoecology 230, 85-128. DO] 10.1016/j.palaeo.2005.07.009

Moy-Thomas, J.A. \& DYNE, M.B. 1938. The actinopterygian 
fishes from the Lower Carboniferous of Glencartholm, Eskdale, Dumfriesshire. Transactions of the Royal Society of Edinburgh $59,437-480$.

NIELSEN, E. 1942. Studies on Triassic fishes from East Greenland. I. Glaucolepis and Boreosomus. Palaeozoologica Groenlandica 1, 1-403.

PoHlig, H. 1892. Altpermische Saurierfährten, Fische und Medusen der Gegend vor Friedrichroda i. Thür, 59-64. In Festschrift zum siebenzigsten Geburtstage Rudolf Leuckarts. Wilhelm Engelman Verlag, Leipzig.

Poplin, C. 2001. Le genre Bourbonnella (Actinopterygii, Aeduellidae): révision et description d'une nouvelle espèce du Stéphanien (Carbonifère supérieur) de Montceau-les-Mines (Massif Central, France). Annales de Paléontologie 87(4), 231-248. DOI 10.1016/S0753-3969(01)80012-4

Poplin, C. \& DUTHEIL, D.B. 2005. Les Aeduellidae (Pisces, Actinopterygii) carbonifères et permiens: systématique et étude phylogénétique préliminaire. Geodiversitas 27(1), 17-33.

POPLIN, C. \& LUND, R. 1997. Evolution of the premaxillary in the primitive fossil actinopterygians. Geodiversitas 19(3), $557-565$.

PoPLIN, C.M. \& LUND, R. 2002. Two Carboniferous fine-eyed palaeoniscoids (Pisces, Actinopterygii) from Bear Gulch (USA). Journal of Paleontology 76(6), 1014-1028. DOI 10.1666/0022-3360(2002)076<1014:TCFEPP >2.0.CO;2

ROMER, A.S. 1945. Vertebrate paleontology. $2^{\text {nd }}$ edition. 687 pp. The University of Chicago Press, Chicago \& London.

SCHNEIDER, J.W., GORETZKI, J. \& RÖSSLER, R. 2005. Biostratigraphisch relevante nicht-marine Tiergruppen im Karbon der variscischen Vorsenke und der Innensenken. Courier Forschungsinstitut Senckenberg 254, 103-118.

SCHNEIDER, J.W. \& REICHEL, W. 1989. ChondrichthyerEikapseln aus dem Rotliegenden (Unterperm) Mitteleuropas Schlußfolgerungen zur Paläobiologie paläozoischer Süßwasserhaie. Freiberger Forschungshefte C 436, 58-69.

SCHNEIDER, J.W. \& WERNEBURG, R. 2006. Insect biostratigraphy of the Euramerican continental Late Pennsylvanian and Early Permian, 325-336. In LuCAS, S.G., CASSINIS, G. \& SCHNEIDER, J.W. (eds) Non-Marine Permian Biostratigraphy and Biochronology. Geological Society of London, Special Publications 265.

ŠTAMBERG, S. 1976. Revision of genus Paramblypterus (Actinopterygii) from the Lower Permian of Bohemia. Sborník geologických věd, Paleontologie 18, 9-52.

ŠTAMBERG, S. 1983. Revision of the genus Sceletophorus (Actino- pterygii) from the Carboniferous of the Plzen Basin. Acta Musei reginaehradecensis, Série A - scientiae naturales 18, 43-74.

ŠTAMBERG, S. 1986. Fish Spinarichthys dispersus (Actinopterygii) from the Carboniferous of Bohemia. Acta Universitatis Carolinae, Geologica, Špinar Volume 2, 155-169.

ŠTAMBERG, S. 2002. Actinopterygian fishes from the new Lower Permian locality of the Krkonoše Piedmont Basin. Journal of the Czech Geological Society 47(3-4), 147-154.

ŠTAmBerG, S. 2006. Carboniferous/Permian actinopterygian fishes of the continental basins of the Bohemian Massif, Czech Republic - an overview, 217-230. In LUCAS, S.G., CASSINIS, G. \& SCHNEIDER, J.W. (eds) Non-Marine Permian Biostratigraphy and Biochronology. Geological Society of London, Special Publications 265.

ŠTamberg, S. 2007a. Permo-Carboniferous Actinopterygians of the Boskovice Graben. Part 1. Neslovicella, Bourbonnella, Letovichthys, Elonichthys. 155 pp. Museum of Eastern Bohemia at Hradec Králové.

ŠTAMBERG, S. 2007b. The collection of actinopterygian fishes from the Vrchlabí Formation (Lower Permian, Asselian) of the Krkonoše Piedmont Basin (Bohemia) at the Natural History Museum in Vienna. Acta Musei reginaehradecensis, Série A scientiae naturales 32, 5-10.

ŠTAMBERG, S. \& ZAJíc, J. 2008. Carboniferous and Permian faunas and their occurence in the limnic basins of the Czech Republic. 224 pp. Museum of Eastern Bohemia at Hradec Králové.

UHL, D. 1997. Erstnachweis der Gattung Bourbonnella (Aeduelliformes, Actinopterygii) aus dem Unteren Rotliegend (Unter Perm) des Saar-Nahe-Beckens (Sw-Deutschland). Mitteilungen der Polichia 84, 7-13.

WESTOLL, T.S. 1937. On a remarkable fish from the Lower Permian of autun, France. Annals and Magazine of Natural History 10(19), 553-578.

WESTOLL, T.S. 1944. The Haplolepidae, a new family of Late Carboniferous bony fishes. A study in taxonomy and evolution. Bulletin of the American Museum of Natural History 83(1), $1-121$.

YANKEVICH, D.I. \& MINICH, M.G. 1998. Ichthyofauna, 256-266. In Grunt, T.A., ESAUlOvA, N.K. \& KANEV, G.P. (eds) Biota of East European Russia at the Early/Late Permian boundary (International Symposium "Upper Permian stratotypes of the Volga region"). Moscow, GEOS. [in Russian]

ZAJíC, J. 2007. Carboniferous Fauna of the Krkonoše Piedmont Basin. Acta Musei reginaehradecensis, Série A - scientiae naturales 32, 11-16. 